\title{
PENERAPAN PRINSIP ANDRAGOGIK OLEH TUTOR PADA PELATIHAN MAKE UP WARDAH COSMETIC DI KOTA PADANG
}

\author{
Musarah', ${ }^{1,2}$, Jamaris ${ }^{1}$, Jalius ${ }^{1}$ \\ ${ }^{1}$ Universitas Negeri Padang \\ Email: musarahfadhillah4169@gmail.com
}

\begin{abstract}
This research is based on the high interest and participation of the participants of make up training because the tutor applies the principles of andragogik on Wardah Cosmetic training process in Padang City. So this study aims to illustrate the application of principles andragogik by Tutor seen from the performance, environmental management of learning environment, and implementation of learning evaluation. Type This research is a quantitative descriptive with the population is the trainer participants to be sampled by mengguanakan cluster random sampling technique. Data collection tool used is a questionnaire with data analysis of percentage calculations. The result of the research shows that in general the Application of Andragogic Principle by Tutor In Wardah cosmetic Make Up Training in Padang City has been running well, viewed from the performance of tutor, the management of learning environment atmosphere, the implementation of learning evaluation.
\end{abstract}

Keyword: Principles of Andragogy

\section{PENDAHULUAN}

Pendidikan merupakan jalan utama untuk mengembangkan watak serta dalam rangka mencerdaskan kehidupan bangsa dan mengembangkan potensi manusia yang beriman dan bertaqwa kepada Tuhan Yang Maha Esa karena pada dasarnya pendidikan bertujuan mengembangkan potensi diri individu agar individu menjadi kreatif, berilmu, mandiri, cakap, berakhlaq mulia, serta memiliki keterampilan. Pada dasarnya pendidikan itu terdiri dari tiga jalur yaitu pendidikan formal, informal dan nonformal (Jannah, 2013).

Sudjana (2010), berpendapat bahwa pendidikan luar sekolah, sebagai bagian dari pendidikan nasional yang program-programnya berkaitan dengan berbagai sektor pembangunan, adalah wajar untuk memantapkan tugas pokoknya agar berorientasi pada perubahan masyarakat yang mungkin terjadi di masa depan. Melalui pendidikan dipandang sebagai proses belajar sepanjang hayat manusia. Artinya pendidikan merupakan upaya manusia untuk mengubah dirinya ataupun peserta lain selama ia hidup.

Pelatihan suatu program meningkatkan kemampuan peserta, menambah pengetahuan, meningkatkan pengetahuan, serta mengembangkan ilmu pengetahuan (Kandou, 2013). Ada pun yang menjadi sasaran pelatihan make up ini adalah diprioritaskan pada masyarakat umum dengan rentang usia 17-35 tahun. Program pelatihan disesuaikan dengan kebutuhan dan minat warga belajar berdasarkan kebutuhan dan potensi yang ada di lingkungan masyarakat saat ini. Keuntungan yang diharapkan dari program ini adalah warga belajar dapat memanfaatkan hasil belajarnya dalam kehidupan sehari-hari guna peningkatan kesejahteraan hidupnya.

Program ini menuntut keterampilan tutor yang memadai. Peran tutor tidak hanya pada proses dalam pelatihan akan tetapi mulai dari performansi tutor, pengelolaan suasana lingkungan belajar, dan mengevaluasi proses pelatihan. Pelatihan make up perlu melibatkan warga belajar mulai dari perencanaan belajar sampai penilaian hasil belajar.

Tutor mempunyai peran penting dalam menentukan keberhasilan program pelatihan make up. Tutor bertanggung jawab mengidentifikasi kebutuhan dan minat warga belajar dalam merencanakan kegiatan pelatihan. Informasi tersebut berguna untuk membantu warga belajar yang memiliki tingkat 
keterampilan yang berbeda. Tutor bertindak sebagai pendidik dan fasilitator dalam sumber belajar. Sebagai sumber belajar tutor bertanggung jawab mensiasati suatu pola kegiatan belajar. Pola ini berwujud peran serta tutor dalam pembelajaran (Nuryaman, 2010). Masalahnya apakah tutor mampu melaksanakan tugasnya sangat kompleks dalam penerapan pada peserta pelatihan make up.

Program yang diselenggarakan oleh PT. Paragon Wardah Cosmetic Kota Padang untuk membekali peserta dengan pengetahuan dan keterampilan yang diperlukan di lapangan kerja yang tersedia serta untuk merintis kesempatan kerja baru. Ada 60 peserta yang terdaftar sebagai peserta pelatihan make up di Kota Padang, dari 60 peserta yang telah mendaftar sebagai peserta pelatihan make up dibagi mejadi dua kelompok karena menimbang keefektifan proses kegiatan pelatihan, dan peserta yang mendaftar umumnya semua telah menginjak usia dewasa.

Tabel 1

Peningkatan Jumlah Peserta Pelatihan Make Up Wardah Cosmetic Kota Padang 2014-2016

\begin{tabular}{cccccc}
\hline No & Tahun & Januari-April & Juli-September & Oktober-Desember & $\begin{array}{c}\text { Jumlah Peserta } \\
\text { Keseluruhan }\end{array}$ \\
\hline 1 & 2014 & 12 & 15 & 19 & 46 \\
2 & 2015 & 22 & 28 & 33 & 83 \\
3 & 2016 & 35 & 39 & 43 & 117 \\
4 & 2017 & 52 & 58 & 60 & 170 \\
\hline
\end{tabular}

Tabel 1 di atas menunjukkan bahwa peserta yang mengikuti pelatihan periode Januari-April 2014 sebanyak 12 peserta, bulan Juli-September 2014 sebanyak 15 peserta, dan bulan OktoberDesember 19 peserta, Jadi jumlah keseluruhan yang ikut pelatihan make up tahun 2014 sebanyak 46 peserta. Tahun 2015 periode Januari-April peserta pelatihan berjumlah 22 peserta, bulan JuliSeptember 2015 sebanyak 28 peserta, dan bulan Oktober-Desember 2015 sebanyak 33 peserta, jadi jumlah peserta pelatihan make up keseluruhan 83 peserta. Tahun 2016 periode Januari-April jumlah peserta pelatihan make up 35 peserta, Juli-September 2017 berjumlah 39 peserta, dan OktoberDesember 201743 peserta, jadi jumlah keseluruhan 117 peserta peserta. Periode Januari-April berjumlah 52 peserta, bulan Juli-September jumlah peserta pelatihan 58 peserta, dan periode OktoberSeptember 60 peserta. Jadi jumlah keseluruhan 170 peserta. Terdapat suatu peningkatan peserta yang mengikuti pelatihan make up dari tahun ke tahun di kantor Wardah Cosmetic di Kota Padang.

Tutor melakukan penerapan prinsip andragogik sehingga mereka dalam belajar lebih mudah memahami. Cara peserta dewasa belajar sangat berbeda jauh dengan anak-anak belajar, mereka belajar suatu proses penemuan sepanjang hayat terhadap apa yang dibutuhkan untuk diketahui dan digunakan dalam kehidupan, hal ini yang membedakannya dengan cara belajar anak-anak. Oleh karena itu, untuk membelajarkan peserta dewasa harus memperhatikan penerapan belajarnya.

Hasil observasi yang penulis lakukan pada tanggal 7 dan 14 Januari 2017 penulis melihat bahwa pelaksanaan pelatihan make up berlangsung sangat kondusif, pelatihan dimulai dari pukul 9 pagi sampai dengan 4 sore, meskipun jam pelatihan cukup lama penulis melihat peserta sangat antusias dan semangat pada saat proses pembelajaran, tidak terlihat peserta yang keluar masuk selama jam pelajaran.

Hasil wawancara peneliti pada tanggal, 15 April 2017 dengan Mbak Aulia, selaku penyelenggara program pelatihan make up, diperoleh informasi bahwa "Proses pelatihan berlangsung sangat baik, peserta rajin menghadiri pelatihan sesuai dengan jadwal yang sudah ditentukan". Pernyataan Mba Aulia tersebut sesuai dengan observasi yang penulis lakukan pada tanggal , 22, dan 23 April 2017 pada pelatihan terlihat peserta selalu hadir dan tidak ada yang datang terlambat, semua peserta hadir mengikuti pembelajaran di setiap pertemuan yang diadakan 2 kali dalam seminggu.

Tutor terlihat begitu energik atau bersemangat memberikan materi dan praktik pada proses pelatihan. Ketika pelatihan berlangsung peserta tidak sungkan bertanya kepada tutor apabila belum mengerti terhadap materi dan praktik yang diajarkan, peserta pelatihan hampir 50\% di antaranya memberikan pertanyaan dan pendapatnya, setiap peserta berlomba-lomba menciptakan karya, berpacu mengembangkan kreatifitas dan selalu berupaya untuk lebih inovatif, menemukan cara baru yang lebih baik dan efesien untuk menyelesaikan pekerjaan mereka. 
Membelajarkan peserta dewasa diduga dilakukan dengan menggunakan penerapan-penerapan andragogik sehingga mereka dalam belajar lebih mudah memahami. Cara peserta dewasa belajar sangat berbeda jauh dengan anak-anak belajar, mereka belajar adalah proses penemuan sepanjang hayat terhadap apa yang dibutuhkan untuk diketahui dan digunakan dalam kehidupan, hal ini yang membedakannya dengan cara belajar anak-anak. Penerapan andragogik tersebut peserta pelatihan make up dapat memahami maksud dari pelatihan yang diberikan oleh tutor, di mana pelatihan ini sangat berguna bagi dirinya dan keterampilan yang dimilikinya.

\section{METODE}

Jenis penelitian yang dipakai adalah deskriptif kuantitatif, melalui penelitian ini, penulis berusaha mendeskripsikan suatu gejala, kejadian, peristiwa yang terjadi di lapangan apa adanya tanpa melakukan penambahan atau intervensi terhadap sasaran penelitian (Irfan, 2016). Pada penelitian ini variabel yang diteliti yaitu penerapan prinsip-prinsip andragogik oleh tutor pelatihan make up Wardah Cosmetic di Kota Padang. Jenis data yang dikumpulkan dalam penelitian ini untuk melihat deskripsi performansi tutor, pengelolaan suasana lingkungan belajar, dan pelaksanaan evaluasi belajar. Populasi penelitian ini adalah peserta pelatihan make up yang berjumlah 60 orang di Wardah Cosmetic Kota Padang. Teknik yang digunakan dalam penarikan sampel adalah purposive sampling.

Keseluruhan jumlah populasi maka persentase sampel yang diambil dalam penelitian ini adalah 50\%. Jadi jumlah sampel dalam penelitian ini adalah sebanyak 30 orang. Teknik yang digunakan untuk mengumpulkan data pada penelitian ini adalah penyebaran kuesioner, sedangkan alat pengumpul data yang digunakan adalah kuesioner. Analisis data dalam penelitian ini adalah menggunakan rumus persentase (A. M. Yusuf, 2010).

\section{HASIL PENELITIAN DAN PEMBAHASAN Hasil Penelitian}

Hasil penelitian mengenai penerapan prinsip-prinsip andragogik oleh tutor pada pelatihan make up Wardah Cosmetic di Kota Padang dapat diuraikan sebagai berikut.

Gambar 1

Penerapan Prinsip Andragogik oleh Tutor pada Pelatihan Dilihat dari Aspek Performansi Tutor

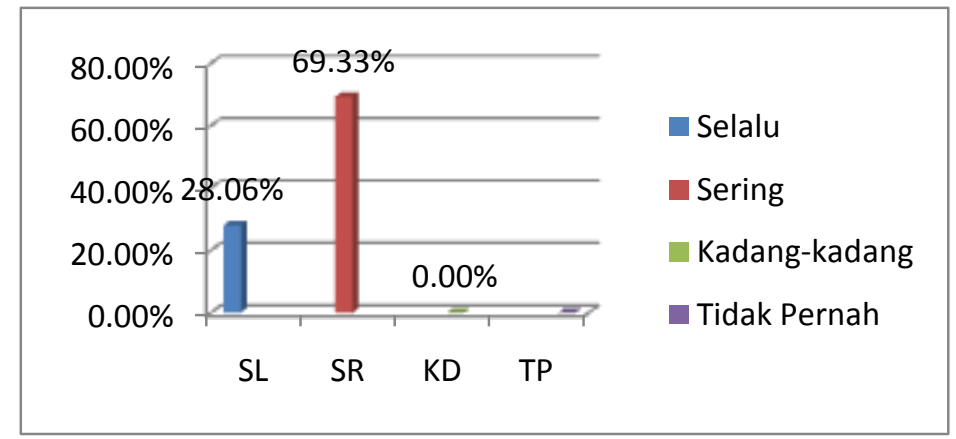

Analisis data pada Gambar 1, disimpulkan bahwa performansi tutor pada pelatihan make up baik, karena terlihat dari jumlah responden yang memilih alternatif jawaban sering. Rangkuman jawaban yang diterima oleh peneliti menunjukan penerapan prinsip andragogik dari aspek performansi tutor pelatihan make up di Wardah Cosmetic Kota Padang, disimpulkan performansi tutor yang baik dapat memengaruhi keberhasilan dalam belajar. Melalui pelatihan make up, responden berharap tutor dapat mempertahankan performansi yang ia miliki. 
Gambar 2

Penerapan Prinsip Andragogik oleh Tutor pada Pelatihan dilihat dari Aspek Pengelolaan Suasana Lingkungan Belajar

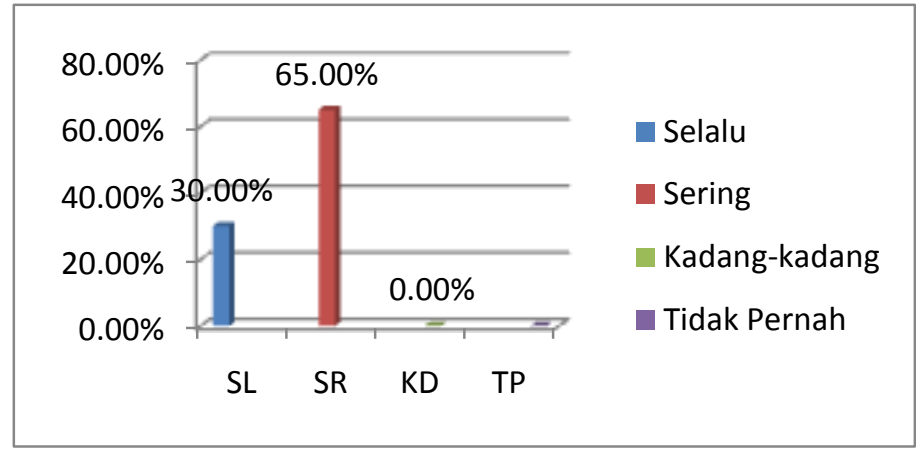

Analisis data pada Gambar 2, disimpulkan penerapan prinsip andragogik oleh tutor pada pelatihan make up sangat baik dapat memengaruhi kemauan peserta dalam pelatihan. Dapat dijelaskan bahwa penerapan prinsip-prinsip andragogik oleh tutor dilihat dari pengelolaan suasana lingkungan belajar sangat baik, karena terlihat dari jumlah responden yang memilih alternatif jawaban sangat selalu.

Gambar 3

Penerapan Prinsip Andragogik oleh Tutor pada Pelatihan

Dilihat dari Aspek Pelaksanaan Evaluasi Belajar

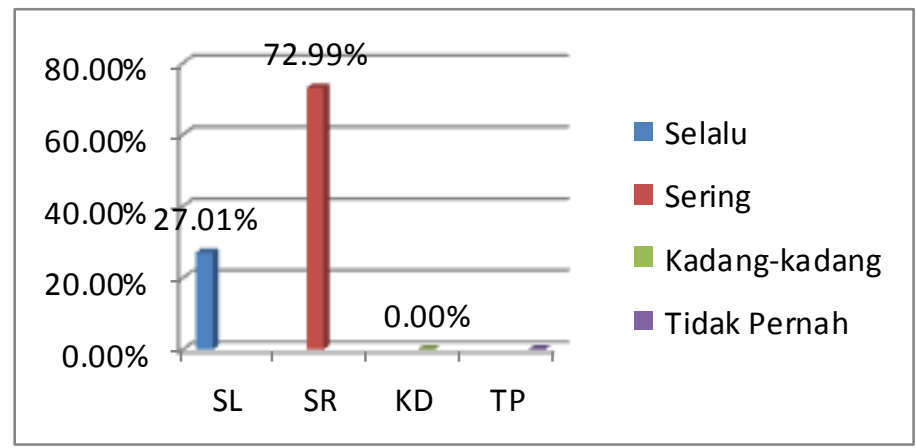

Analisis data pada Gambar 3, disimpulkan bahwa gambaran penerapan prinsip andragogik oleh tutor pada pelatihan make up dilihat dari aspek pelaksanaan evaluasi belajar baik, karena terlihat dari jumlah responden yang memilih alternatif jawaban sangat sering. Disimpulkan pelaksanaan evaluasi belajar yang baik dapat memengaruhi keberhasilan dalam pelatihan.

\section{Pembahasan}

Hasil penelitian yang dikemukakan pada bagian sebelumnya, maka langkah selanjutnya adalah menganalisis data tersebut berdasarkan kajian teori dan juga teori-teori lainnya yang relevan, untuk lebih lanjut sebagai berikut.

\section{Gambaran Penerapan Prinsip Andragogik oleh Tutor pada Pelatihan Dilihat dari Aspek Performansi}

Hasil penelitian tentang gambaran penerapan prinsip-prinsip andragogik oleh tutor pada pelatihan make up ditinjau dari aspek performansi tutor, sebagian besar responden mengatakan bahwa penerapan prinsip-prinsip andragogik baik ditinjau dari performansi tutor pada saat proses pelatihan berlangsung. Dalam performansinya, tutor memengaruhi motivasi peserta dalam proses kegiatan yang dipimpinnya dalam pelatihan. 
Solfema (2013) berpendapat bahwa pendidik yang berpenampilan menyenangkan akan dinilai positif oleh peserta didik, sehingga mempertinggi motivasinya untuk belajar pada yang pada gilirannya, meskipun peserta didik tersebut berkemampuan rendah, akan mendorongnya untuk mencapai sukses dalam kegiatan pembelajaran.

Uraian di atas dapat disimpulkan dalam suatu kegiatan pelatihan memerlukan performansi yang baik oleh tutor, agar terjalin komunikasi yang baik antara tutor dengan peserta pelatihan sehingga proses pelatihan berlangsung sesuai dengan kebutuhan peserta. Hasil penelitian yang ditemukan di lapangan tentang penerapan prinsip andragogik oleh tutor pada pelatihan make up dilihat dari aspek performansi baik. Karena pada program pelatihan tutor harus memiliki performansi yang baik terlebih dahulu agar proses pelatihan berlangsung dengan baik dan berjalan sesuai dengan semestinya.

\section{Gambaran Penerapan Prinsip Andragogik oleh Tutor pada Pelatihan Dilihat dari Aspek Pengelolaan Suasana Lingkungan Belajar}

Hasil penelitian tentang gambaran penerapan prinsip-prinsip andragogik oleh tutor pada pelatihan make up ditinjau dari aspek pengelolaan suasana lingkungan belajar, sebagian besar responden mengatakan bahwa tutor telah melakukan pengelolaan suasana lingkungan belajar dengan baik ditinjau dari proses kegiatan pelatihan berlangsung, seperti lingkungan fisik. Dalam melaksanakan kegiatan pelatihan, tutor melakukan pengelolaan suasana lingkungan belajar yang baik, sehingga peserta pelatihan merasa nyaman ketika pelatihan berlangsung.

Morgan, dkk berpendapat bahwa pengelolaan lingkungan fisik di antaranya berhubungan dengan penataan ruangan atau tempat belajar, Ruangan perlu ditata dengan sedemikian rupa sehingga memungkinkan udara dan cahaya masuk secukupnya untuk kesegaran belajar, dalam ruangan yang segar dan menyenangkanlah potensi belajar peserta didik akan dapat berkembang secara optimal (Solfema, 2013). Disimpulkan bahwa pengelolaan lingkungan suasana belajar pada proses pelatihan berlangsung yang dilakukan oleh tutor berjalan dengan baik sesuai dengan yang semestinya diharapkan oleh peserta pelatihan.

Lunanda berpendapat bahwa pengelolaan lingkungan fisik kepada peserta didik hendaknya diberikan kebebasan untuk memanfaatkan dan bahkan melengkapi sarana belajar tanpa membedakan antara satu peserta didik dengan yang lainnya, kebebasan dalam menggunakan sarana belajar tanpa membedakan antara satu peserta didik dengan yang lainnya dapat mencerminkan kesamaan hak yang memang diperlukan dalam membelajarkan orang dewasa (Solfema, 2013).

Hasil penelitian yang ditemukan di lapangan tentang penerapan prinsip andragogik oleh tutor dilihat dari aspek pengelolaan suasana lingkungan belajar berlangsung dengan baik. Karena di dalam pengelolaan suasana lingkungan belajar, tutor berperan menyiapkan kondisi tempat belajar, memonitor kegiatan peserta pelatihan dan memberikan motivasi kepada peserta pelatihan agar tercapainya tujuan pembelajaran yang diinginkan.

\section{Gambaran Penerapan Prinsip Andragogik oleh Tutor pada Pelatihan Dilihat dari Aspek Pelaksanaan Evaluasi Belajar}

Hasil penelitian tentang gambaran penerapan prinsip andragogik oleh tutor pada pelatihan make up ditinjau dari aspek pelaksanaan evaluasi belajar, sebagian besar peserta didik mengatakan bahwa dalam melaksanakan evaluasi hasil belajar, tutor melaksakan evaluasi berupa tes lisan, tulisan dan praktek. Kemudian tutor mengolah dan menganalisis hasil tersebut untuk mengukur tingkat pemahaman warga belajar dan melihat apakah kegiatan yang sudah dilaksanakan telah mencapai tujuan yang ditetapkan.

Syamsu Mappa berpendapat bahwa evaluasi program pendidikan luar sekolah sebagai kegiatan yang dilakukan untuk menetapkan keberhasilan atau kegagalan suatu program pendidikan. Penilaian yang dilakukan dapat terjadi ketika sedang berlangsung atau setelah adanya kegiatan. Penilaian sangat penting karena dengan adanya evaluasi kita dapat melihat apakah kegiatan yang sudah dilaksanakan mencapai tujan yang telah ditetapkan (Hurmaini, 2013).

Pendapat di atas maka dapat disimpulkan bahwa untuk melihat suatu hasil belajar sesuai dengan tujuan, digunakan evaluasi. Pada tahap evaluasi program pembelajaran sumber belajar dan warga belajar dilibatkan dalam menentukan apa yang akan dievaluasi, bagaimana evaluasi dilakukan, 
dan kapan saja evaluasi akan dilakukan. Tugas tutor dalam menilai pembelajaran meliputi melakukan penilaian dengan menggunakan intrumen penilaian yang telah disusun dalam rencana pembelajaran, dan memberikan masukan serta tindak lanjut perbaikan. Keterampilan yang diperlukan untuk melaksanakan penilaian antara lain teknik dan alat penilaian, kriteria penilaian yang baik, bentuk dan jenis tes, dan penskoran.

Hasil pembelajaran adalah semua efek yang dapat dijadikan sebagai indikator tentang nilai dan penggunaan strategi pembelajaran di bawah kondisi yang berbeda. Keberhasilan pembelajaran dapat diukur melalui keefektifan, efesiensi dan daya tarik. Hasil penelitian yang peneliti temukan di lapangan sesuai, yaitu tutor melalakukan evaluasi belajar ketika kegiatan sedang berlangsung atau setelah kegiatan berlangsung.

\section{KESIMPULAN DAN SARAN Kesimpulan}

Hasil penelitian pada bab sebelumnya, maka dapat diambil kesimpulan bahwa: (1) Gambaran penerapan prinsip andragogik oleh tutor pada pelatihan make up Wardah Cosmetic di Kota Padang dilihat dari performansi, dikategorikan baik. (2) Gambaran penerapan prinsip andragogik oleh tutor pada pelatihan make up Wardah Cosmetic di Kota Padang dilihat dari pengelolaan suasana lingkungan belajar, dikategorikan baik. (3) Gambaran penerapan prinsip andragogik oleh tutor pada pelatihan make up Wardah Cosmetic di Kota Padang dilihat dari pelaksanaan evaluasi belajar, dikategorikan baik.

\section{Saran}

Berdasarkan hasil penelitian, pembahasan dan kesimpulan yang telah disimpulkan diatas, maka peneliti mencoba memberikan saran sebagai berikut: (1) Diharapkan tutor untuk mempertahankan performansi yang dimilikinya selama ini, sehingga tercapainya tujuan pembelajaran secaa optimal demi meningkatkan sumber daya manusia yang berkualitas. (2) Kepala lembaga pelatihan untuk lebih meningkatkan materi dan metode yang akan diberikan tutor agar peserta pelatihan lebih termotivasi lagi untuk mengikuti pelatihan. (3) Bagi peneliti selanjutnya dapat dijadikan sebagai bahan referensi khususnya mengenai penelitian yang berhubungan dengan judul peneliti. Sebagai contoh bagi tutor, peserta pelatihan, dan kepala lembaga dalam pelatihan make up.

\section{DAFTAR RUJUKAN}

Hurmaini, M. (2013). Evaluasi Program Pendidikan Luar Sekolah/Pelatihan Orang Dewasa. EduMath, 4, 1-12. Retrieved from journal.iainjambi.ac.id/index.php/edumath/article/download/249/229

Irfan, A. Z. (2016). Kegiatan Bermain Peran dalam Pengembangan Kemampuan Kecerdasan Interpersonal. Jurnal Realita, 1(2), 188-195. Retrieved from http://fip.ikipmataram.ac.id/wpcontent/uploads/2015/03/M-Zainul-Irfan_KEGIATAN-BERMAIN-PERAN-DALAMPENGEMBANGAN-KEMAMPUAN-KECERDASAN-INTERPERSONAL.pdf

Jannah, F. (2013). Pendidikan Seumur Hidup dan Implikasinya. Dinamika Ilmu, 13(1), 1-16. Retrieved from https://iain-samarinda.ac.id/ojs/index.php/dinamika_ilmu/article/view/19/18

Kandou, E. E. (2013). Pengaruh Pelatihan dan Pengembangan Karyawan terhadap Produktivitas Kerja Karyawan (Studi pada PT. Air Manado). Jurnal Acta Diurna, 2(3), 1-12. Retrieved from https://ejournal.unsrat.ac.id/index.php/actadiurna/article/download/2435/1972

Nuryaman, Y. (2010). Hubungan Pendampingan Tutor dengan Motivasi Belajar Warga Belajar Program Pendidikan Kesetaraan Paket B di Pusat Kegiatan Belajar Masyarakat (PKBM) Gema Insan Peduli Umat (GIPU). Jurnal Pendidikan Luar Sekolah, 5(2). Retrieved from http://ejournal.upi.edu/index.php/pls/article/download/1210/850

Solfema. (2013). Andragogi Konsep dan Penerapannya. Malang: Wineka Cipta.

Sudjana, D. (2010). Pendidikan Nonformal. Bandung: Penerbit Falah Production.

Yusuf, A. M. (2010). Metodologi Penelitian. Padang: UNP Press. 